\title{
Corporate Strategies for a Circular Economy: A Comparative Study of Energy Companies
}

\author{
Daisy de Selliers, Catalina Spataru \\ University College London, UK
}

\begin{abstract}
.
The Circular Economy (CE) concept is considered as an approach to ensure sustainable development and minimise environmental impacts of economic activities. However, its implementation in businesses appears in its infancy. Achieving the CE requires changes and innovation at technical, organisational and supply chain level. Through an exploration of the literature on the integration of the CE in business strategies and a case study analysis of selected energy companies, this paper aims at highlighting circular measures already implemented and circular opportunities embeddable in business models. Findings suggest that case companies are active in waste management, resource efficiency, sustainable procurement, energy recovery techniques and low carbon generation. However, few case companies mention the concept of $\mathrm{CE}$ as part of their business model. In particular, systematic approach for planning for end-of-life plants and products, as well as multistakeholders collaboration for waste and resource use optimisation could support the CE transition. The paper proposes directions for further research: in-depth analyses focusing on supply chains, development of a methodological approach to support decision-making and definition of global consensus and consistent objectives to achieve sustainability.
\end{abstract}

Keywords: Corporate Strategy, Strategic Management, Sustainable Development, Circular Economy, Circular Business Models, Corporate Sustainability

\section{Introduction}

The Circular Economy (CE) has received increasing attention as an approach to address sustainability issues associated with the current economic system. A CE can be defined as "an industrial system that is restorative or regenerative by intention and design" (Ellen Macarthur Foundation, 2013). It would eliminate or minimize waste and by-products in order to prevent environmental pollution, resource depletion and climate change. It would facilitate the transition towards sustainable development, defined as "the ability to meet the needs of the present without compromising the ability of future generations to meet their own needs" (United Nations, 1987). In addition, the CE principles uncover sources of economic value creation potential (Ellen Macarthur Foundation, 2013). 
However, despite growing support worldwide, its implementation still appears to be in early stages (Kirchherr et al., 2018). Identified barriers include the rigidity of businesses' and customers' behaviour, the lack of institutional framework and incentives, the lack of technology and infrastructure, the large capital requirements and initial costs, and the uncertain return on investment (de Jesus and Mendonça, 2018).

The CE can be implemented across any sector. The literature includes case studies on the pharmaceutical industry (Veleva, Bodkin and Todorova, 2017), the construction industry (Gorecki, 2019), the manufacturing industry (Sousa-Zomer et al., 2018), the food and beverage industries (D'Amato, Korhonen and Toppinen, 2019). However, limited literature has focused on the case of power generation companies by considering their strategy and business models. Energy companies can play an important role in the transition towards a sustainable circular system through various aspects: the need to reduce greenhouse gas emissions associated with energy production, the use of biofuels and waste for energy production, the recovery of end-of-life plants and equipment, the choice of materials and design of generating technologies, the treatment of waste and wastewater, the recycling of by-products such as ash from fuel combustion, the potential of carbon recycling, etc.

In order to support the transition to the $\mathrm{CE}$, business models and strategies must be reviewed and adjusted. Therefore, this paper explores the following question: How can companies integrate circularity in their business strategy with the aim of achieving sustainable development? This paper studies the case of companies responsible for electricity supply and answers the following question: Which practices are implemented in energy companies and how can they further integrate circularity in their business strategy? First, the relevant literature is analysed. Second, the case of selected companies is studied to highlight implemented circular practices. Third, a discussion examines the connections and gaps between the literature and the case study findings. Finally, the paper concludes and points out directions for further research.

\section{Methodology}

\subsection{Research Approach}

The research approach consists of two main steps. First, the literature on circular economy and corporate strategy is analysed. Second, selected companies are subject to a case study based comparative analysis. This approach has been chosen in order to confront theoretical findings from the literature with empirical findings from corporate examples. Figure 1 summarises and illustrates the research approach. 


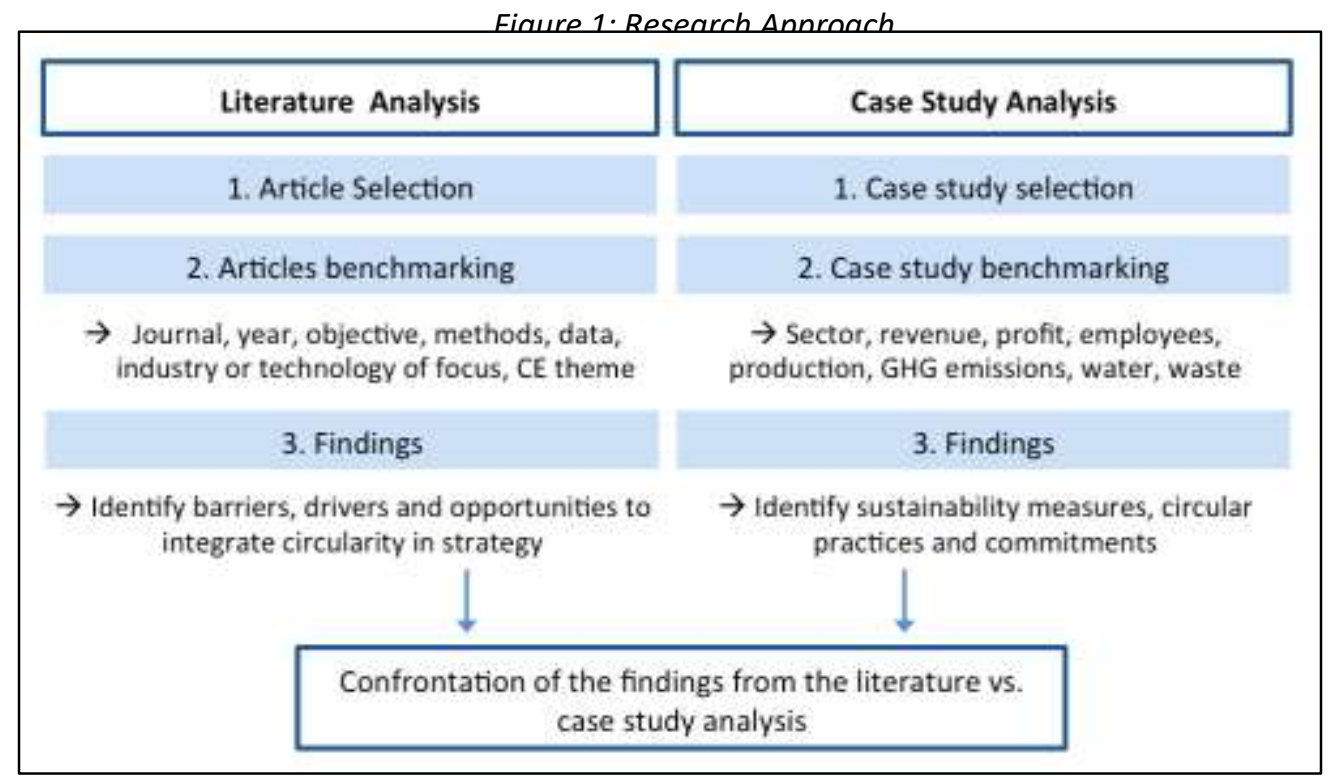

\subsection{Literature Analysis}

A systematic analysis of the academic literature enables to understand the evolution of knowledge on a specific topic. In addition, it enables to identify trends in the research fields and areas for further research. Articles were gathered using a keyword search of articles in Scopus. This database contains peer-reviewed literature and includes books, scientific journals and conference proceedings from multiple disciplines. Scopus has been used given their long-term worldwide multidisciplinary coverage. Two query strings have been entered. The first aims at identifying the literature on the CE and business strategy, while the second aims at extracting articles on the CE and power generation.

\section{QUERY1: Circular economy and strategy}

TITLE-ABS-KEY ( "circular economy" AND "business strategy" OR "corporate strategy") AND ( LIMIT-TO ( PUBSTAGE, "final")) AND ( LIMIT-TO ( DOCTYPE, "ar" OR "CP")

\section{QUERY2: Circular economy and energy}

TITLE-ABS-KEY ("circular economy" AND "power generation" OR "power plant") AND ( LIMIT-TO ( PUBSTAGE, "final")) AND ( LIMIT-TO (DOCTYPE, "ar" OR "cP")

The literature analysis identified in each article the objectives of the research, the industry or technology of focus, the region concerned, the research method(s), the data source(s) and the CE-related main theme.

\subsection{Case Study Analysis}

The case study-based analysis has been designed and structured from the results of the literature analysis. Case study approach is considered as appropriate for investigations on contemporary phenomenon (Geissdoerfer et al., 2018) studied retrospectively with limited control over the events (Yin, 2003). The paper draws on data originating from documents 
published on corporate websites, such as integrated annual reports, sustainability reports or corporate social responsibility report, and investor presentations.

Three steps structure the case study analysis. The first step consists of selecting energy companies. Companies participating in the UN Global Compact have been chosen. This is an initiative developed by the United Nations aimed at supporting companies to responsible business practices (United Nations Global Compact, 2016). The initiative asks participants to follow ten principles related to human rights, labour standards, environment and anticorruption. The three principles related to the environment are the following:

Principle 7: Support a precautionary approach to environmental challenges.

Principle 8: Undertake initiatives to promote environmental responsibility.

Principle 9: Encourage the development of environmentally friendly technologies

There are two main reasons for the focus on UN Global Compact participants. First, access to corporate sustainability data and commitments is facilitated, notably through the requirement to communicate their commitments and produce an annual Communication on Progress. Second, participation shows a willingness to adopt sustainability principles, so that best practices from those companies can be identified. Regarding the case selection, three criteria have been selected: companies with an active status, operating as electric utilities and headquartered in Europe. In addition, only companies owning power generation capacity and publishing reports in English have been analysed.

The second step consists of benchmarking the companies. General indicators, include number of employees, revenue, operating income, power generation and total installed capacity. Indicators related to environmental sustainability include greenhouse gas emissions, water consumption, total waste and percentage of waste recycled. In addition, the strategic direction and investment focus have been examined of each company. Benchmarking technique has been used for biotech and pharmaceutical companies to examine waste reduction strategies (Veleva, Bodkin and Todorova, 2017).

The third step consists of identifying CE business practices implemented in energy companies. Although, most companies do not mention the CE in their corporate report, CErelated practices, such as waste management, material and product recycling, procurement policies, efficiency measures, life cycle considerations, efficiency measures and energy recovery, have been identified in corporate reports.

The research approach of the paper approach is confronted with limitations. First, corporate reports might provide incomplete information on sustainability practices and have been criticised for not tackling the fundamental problems of sustainability. Second, although all companies are electricity producers, they also operate in various business segments, which limits comparisons based on indicators and practices.

\section{Results}

\subsection{Literature Analysis}


The literature analysis shows a recent, but growing academic interest on the circular economy. From the two query searches, 42 articles have been selected for analysis.

Articles from QUERY1 focus on the integration of the circular economy in business models by identifying barriers or challenges of circular business model. 24 articles were considered. Common research approach is exploratory and based on case studies of selected industries. Methods include content analyses, surveys and interviews. Recurrent topics focus on manufacturing companies (Lieder et al., 2017; Sousa-Zomer et al., 2017, 2018; Vogtlander et al., 2017; Bianchini et al., 2018; Oghazi and Mostaghel, 2018; Portillo-Tarragona et al., 2018), construction companies (Christmann, 2018; Gorecki, 2019), small and medium enterprises (SMEs) (Calabrese et al., 2016; Zamfir, Mocanu and Grigorescu, 2017; Caldera, Desha and Dawes, 2019) and industrial symbioses (Walls and Paquin, 2015; Wen and Meng, 2015; Velenturf, 2017). Conceptual analyses and framework developments have also been proposed (Korhonen, Honkasalo and Seppälä, 2018; Laumann and Tambo, 2018; Masi et al., 2018). Aspects for integrating CE in business models include reconfiguration of revenue models and cost structure, collaboration with partners (Oghazi and Mostaghel, 2018), integrated strategy, continuous improvement and stakeholder engagement (Caldera, Desha and Dawes, 2019), mapping of organizational and material relations of the business (Jørgensen and Remmen, 2018), organizational innovation in addition to technological innovation (Gorecki, 2019).

Articles from QUERY2 cover mainly technological advances for a circular economy that are related to energy production. 18 articles were considered. They consist of analyses requiring quantitative data using analytical approaches such as life cycle assessments (LCA), production and demand scenarios, multi-criteria evaluation, techno-economic analyses, as well as case studies. Examples of topics include the recovery of ashes from biomass combustion (Cruz et al., 2017), the recycling of metals in solar technologies (A. dos Reis Benatto, Espinosa and Krebs, 2017), the design of polygeneration systems with offgas recycling (Ng and Martinez Hernandez, 2016), the potential of carbon capture and utilisation (Naims, 2016), the co-valorisation of waste through industrial symbioses (Manara and Zabaniotou, 2016), the eco-design of renewable technologies (Gallagher et al., 2019), the proposal of scenarios for landfill management (Bučinskas, Kriipsalu and Denafas, 2018), and the reliability of waste for energy recovery (Islam and Jashimuddin, 2017).

This literature review enables to extract a comprehensive definition of circular business models: "the rationale of how an organization creates, delivers, and captures value with slowing, closing, or narrowing flows of the resource loops" (Oghazi and Mostaghel, 2018). Circular business strategies are designed to be aligned with environmental sustainability and provide environmental and social value, in addition to economic value. Such strategies would implement circularity in business activities and value chains. Some circular practices are general to any organisations, while others are specific to energy production. Table 1 presents circular economy strategies covered by the literature under QUERY1 and QUERY2.

Table 1: Circular Economy Strategies 


\begin{tabular}{|c|c|}
\hline \multicolumn{2}{|c|}{ Waste management } \\
\hline $\begin{array}{l}\text { 4Rs principles (Kalmykova, Sadagopan and } \\
\text { Rosado, 2018): } \\
\text { - Waste reduction } \\
\text { - Waste reuse } \\
\text { - Waste recovery } \\
\text { - Waste recycling }\end{array}$ & $\begin{array}{l}\text { Recycling of ash from coal and biomass combustion (Cruz } \\
\text { et al., 2017; Fuller et al., 2018; Millward-Hopkins and } \\
\text { Purnell, 2019) } \\
\text { Carbon capture and utilisation (Naims, 2016) } \\
\text { Valorisation of glycerol from biodiesel plants (Manara } \\
\text { and Zabaniotou, 2016) }\end{array}$ \\
\hline \multicolumn{2}{|c|}{ Product management } \\
\hline $\begin{array}{l}\text { Circular product design } \\
\text { Eco-design and eco-innovation } \\
\text { Product stewardship } \\
\text { Product recycling, downcycling or upcycling }\end{array}$ & $\begin{array}{l}\text { Metal recycling in generation technologies: renewables } \\
\text { (Gallagher et al., 2019), photovoltaics (A. dos Reis } \\
\text { Benatto, Espinosa and Krebs, 2017), fuel cells (Stropnik } \\
\text { et al., 2018) }\end{array}$ \\
\hline \multicolumn{2}{|c|}{ Resource management } \\
\hline $\begin{array}{l}\text { Energy efficiency } \\
\text { Energy recovery } \\
\text { Water efficiency } \\
\text { Water treatment and recycling } \\
\text { Material efficiency } \\
\text { Material substitution (e.g. to renewable or bio- } \\
\text { based materials) }\end{array}$ & $\begin{array}{l}\text { Energy recovery: from municipal waste (Islam and } \\
\text { Jashimuddin, 2017; van der Roest et al., 2017), } \\
\text { microalgae (Fernández-Acero et al., 2019), wood-waste } \\
\text { (Buonocore et al., 2019; Millward-Hopkins and Purnell, } \\
\text { 2019), wine production (Donia, Mineo and Sgroi, 2018) } \\
\text { Use of renewable power for plastic production (Palm, } \\
\text { Nilsson and Åhman, 2016) }\end{array}$ \\
\hline \multicolumn{2}{|c|}{ Supply chain } \\
\hline $\begin{array}{l}\text { Sustainable or green procurement } \\
\text { Industrial symbiosis } \\
\text { Polygeneration systems } \\
\text { Waste exchange }\end{array}$ & $\begin{array}{l}\text { Offgas recycling for methanol production ( } \mathrm{Ng} \text { and } \\
\text { Martinez Hernandez, 2016) } \\
\text { Waste exchanges between coal power producer and } \\
\text { cement producer (Dong et al., 2017) }\end{array}$ \\
\hline \multicolumn{2}{|c|}{ Customers and community } \\
\hline $\begin{array}{l}\text { Recovery of end-of-life products } \\
\text { Community involvement } \\
\text { Socially responsible consumption }\end{array}$ & $\begin{array}{l}\text { Energy generation on underused spaces: rooftops } \\
\text { (Corcelli et al., 2019), landfill (Bučinskas, Kriipsalu and } \\
\text { Denafas, 2018) }\end{array}$ \\
\hline
\end{tabular}

\subsection{Case Study Analysis}

The case of energy firms enables to study and develop their role in the transition to a circular economy. The liberalisation of energy markets in Europe resulted in the opening up to competition and environmental complexity of energy actors (Capece, Pillo and Levialdi, 2013). They engage in multiple business activities besides power generation, such as energy management services, gas sales, electricity trading, green certificates and power purchase agreements. Therefore, the integration of circularity in their strategy must cover and be coordinated across the entire scope of their activities. Sustainability measures in the energy sector have focused on the reduction of greenhouse gas emissions, given the risks and impacts of climate change on human and natural systems reaffirmed by the IPCC (Gasbarro, Iraldo and Daddi, 2017). However, other sustainability pressures, such as material resource depletion, waste disposal and water scarcity, also involve energy companies. A report from the World Bank shows that technologies assumed to enable a low carbon transition are more material intensive than the traditional fossil fuel based system (World Bank, 2017). Metals such as lithium used in batteries, indium and tellurium used in solar technologies and dysprosium used in wind turbines might present supply risk in the long term (de Selliers and Spataru, 2018). Therefore, energy technologies must be designed and developed in a circular 
way so to reuse them or recycle their components at the end of life. In addition, circular opportunities can be found in the recovery of by products of energy production and in the production of energy from industrial, commercial or municipal waste.

For the purpose of the research, 14 energy companies have been analysed. Their commonalities are: electricity production as core business activity, headquarters' location in Europe and participation to the UN Global Compact. The most recent corporate reports published on their websites have been used to extract data related to business model, strategy, environmental management and practices, and circular measures. Table 2 presents key general data for the case companies ranked by number of employees.

Table 2: Presentation of case companies

\begin{tabular}{|c|c|c|c|c|c|c|}
\hline Name & Headquarters & $\begin{array}{c}\text { Outside } \\
\text { Europe? }\end{array}$ & $\begin{array}{c}\text { Number of } \\
\text { Employees }\end{array}$ & $\begin{array}{c}\text { Sales 2017 } \\
\text { (Million } € \text { ) }\end{array}$ & $\begin{array}{c}\text { Operating } \\
\text { Profit 2017 } \\
\text { (Million } € \text { ) }\end{array}$ & $\begin{array}{c}\text { Electricity } \\
\text { generated } \\
\text { (GWh) }\end{array}$ \\
\hline Direct Energie & France & No & 333 & 1,966 & 143 & 3,773 \\
\hline Agder Energi & Norway & No & 1,210 & 1,022 & 259 & 8,971 \\
\hline Drax Group & UK & Yes & 2,716 & 4,274 & 266 & 18,300 \\
\hline VERBUND & Austria & No & 2,742 & 2,913 & 922 & 31,130 \\
\hline Edison & Italy & Yes & 3,156 & 5,127 & 289 & 19,700 \\
\hline Orsted & Denmark & Yes & 5,638 & 7,736 & 2,111 & 17,200 \\
\hline MVV Energie & Germany & No & 5,978 & 4,010 & 407 & 1,835 \\
\hline Fortum & Finland & Yes & 8,286 & 4,520 & 1,275 & 74,600 \\
\hline Energa & Poland & No & 9,049 & 2,423 & 497 & 4,290 \\
\hline EDP & Portugal & Yes & 11,631 & 15,745 & 1,521 & 71,963 \\
\hline Enea & Poland & No & 16,193 & 2,682 & 342 & 26,503 \\
\hline SSE plc & UK & No & 20,785 & 33,684 & 3,159 & 33,098 \\
\hline Acciona & Spain & Yes & 37,403 & 7,254 & 356 & 20,431 \\
\hline Enel & Italy & Yes & 69272 & 74639 & 7211 & 249,900 \\
\hline
\end{tabular}


Case companies have a diversified power generation mix with renewable and nonrenewable sources, except Agder Energi that only operates hydroelectric plants. Common business activities other than electricity production include electricity trading, transmission and distribution, gas sales and distribution, and energy services, such as energy management, environmental audit, appliances installations, power purchase agreements and green certificates. In addition, Drax is also a manufacturer of wood pellets for biomass fuel. Agder Energi also operates district-heating plants. MVV Energie is active in drinking water supplies and wastewater disposal. Enea is also a coal miner and producer. Fortum Corporation provides waste management services. Acciona is a conglomerate operating in construction infrastructure, water treatment, and other industrial projects. Strategic directions on which companies focus, are aligned with global trends of energy systems, summarised by decentralisation, decarbonisation and digitalisation. Common ones include customer energy services, low carbon generation, infrastructure development, grid modernisation, decentralised generation and digital technologies.

Regarding environmental sustainability, data on emissions of greenhouse gases (GHG), sulphur oxides (SOx), nitrogen oxides (NOx), particulate matter (PM), waste and water consumption have been extracted from corporate reports. However, those data do not provide support for in-depth comparative analysis given the diversity in methodology and scope. For instance, GHG emissions from Scope 3 category of the GHG Protocol (WRI and WBCSD, 2010) cover indirect emissions: business travel, upstream purchased fuels, purchased electricity sold to end-users, purchased gas sold to end-users, purchased goods and services, equipment, infrastructure, waste treatment, etc. The calculation may differ following several aspects: the activities included, the methodological approach and the emission factors used. The same goes for water and waste data. Some companies report water withdrawn and consumed for operations only, while others expand the coverage. Waste is often separated as hazardous and non-hazardous. Waste handling data include waste recycled (e.g. into raw materials), waste recovered (e.g. into combustion fuel), waste incinerated and waste sent to landfill. Water requirements and waste types differ by process. Analysing water and waste data between sites operating similar processes with similar technological features would enable to compare the efficiency of water and waste management across companies. However, aggregated indicators for entire corporations may limit the comparability of performance of waste and water management. Despite those limitations, an overview of emissions data (GHG, SOx and NOx) and water and waste indicators is presented in table 3 and 4.

Table 3: Emission data

\begin{tabular}{|c|c|c|c|c|c|c|}
\hline Name & $\begin{array}{c}\text { GHG } \\
\text { Emissions - } \\
\text { Scope 1 } \\
\text { (kt CO2 eq) }\end{array}$ & $\begin{array}{c}\text { GHG } \\
\text { Emissions - } \\
\text { Scope 2 } \\
\text { (kt CO2 eq) }\end{array}$ & $\begin{array}{c}\text { GHG } \\
\text { Emissions - } \\
\text { Scope 3 } \\
\text { (kt CO2 eq) }\end{array}$ & $\begin{array}{c}\text { SOX } \\
\text { Emissions } \\
\text { (tons) }\end{array}$ & $\begin{array}{c}\text { NOX } \\
\text { Emissions } \\
\text { (tons) }\end{array}$ & $\begin{array}{c}\text { Kg Scope 1 } \\
\text { GHG Emissions } \\
\text { per MWh } \\
\text { generated }\end{array}$ \\
\hline Direct Energie & 1,082 & - & - & - & 448 & 287 \\
\hline Agder Energi & 4 & - & - & - & 819 & 0 \\
\hline Drax Group & 4,107 & 248 & - & 5,500 & 11,800 & 224 \\
\hline VERBUND & 1,070 & 284 & 338 & 140 & 515 & 34 \\
\hline
\end{tabular}




\begin{tabular}{|c|c|c|c|c|c|c|}
\hline Edison & 7,204 & 168,031 & 12,546 & 837 & 4,618 & 366 \\
\hline Orsted & 3,483 & 151 & 8 & 654 & 2,670 & 203 \\
\hline MVV Energie & 1,547 & 8 & 8,385 & 1,675 & 3,341 & 843 \\
\hline Fortum & 20,100 & 92 & 6,081 & 16,800 & 26,100 & 269 \\
\hline Energa & 2,677 & - & - & 3,864 & 2,765 & 624 \\
\hline EDP & 18,429 & 602 & 11,334 & 21,300 & 14,300 & 256 \\
\hline Enea & 20,208 & - & - & 18,636 & 24,506 & 762 \\
\hline SSE plc & 10,155 & 832 & 10,621 & 1,791 & 5,612 & 307 \\
\hline Acciona & 681 & 547 & 2,295 & 3,351 & 14,683 & 33 \\
\hline Enel & 94,800 & 1,090 & 6,780 & 192,796 & 184,468 & 379 \\
\hline
\end{tabular}

Table 4: Water and waste data

\begin{tabular}{|c|c|c|c|}
\hline Name & Water data & Waste data & Reference \\
\hline Direct Energie & $\begin{array}{c}\text { For } 2 \text { gas turbines only: } \\
\text { Water consumed }=1,829 \text { ktons } \\
\text { Water recycled }=8 \text { ktons }\end{array}$ & $\begin{array}{c}\text { For } 2 \text { gas turbines only: } \\
\text { Hazardous waste }=16 \text { tons } \\
\text { Non hazardous waste }=522 \text { tons } \\
\text { Waste recovery }=72 \%\end{array}$ & $\begin{array}{c}\text { (Direct Energie, } \\
\text { 2017) }\end{array}$ \\
\hline Agder Energi & - & $\begin{array}{c}\text { Total waste }=921 \text { tons } \\
\text { Recycling percentage }=76 \%\end{array}$ & $\begin{array}{c}\text { (Agder Energi, } \\
\text { 2017) }\end{array}$ \\
\hline Drax Group & $\begin{array}{l}\text { Water } \text { withdrawal }=61,700 \text { ktons } \\
\text { Water returned }=42,100 \text { ktons }\end{array}$ & - & (Drax, 2018) \\
\hline VERBUND & $\begin{array}{l}\text { Water withdrawal }=173,934 \text { ktons } \\
\text { (Given by source) } \\
\text { Water discharge }=173,934 \text { ktons }\end{array}$ & $\begin{array}{c}\text { Total waste }=63,398 \text { tons } \\
\text { Hazardous waste }=979 \text { tons } \\
\text { Non hazardous waste }=46,161 \text { tons }\end{array}$ & $\begin{array}{l}\text { (Verbund, } \\
\text { 2018) }\end{array}$ \\
\hline Edison & $\begin{array}{c}\text { Water used }=483,949 \text { ktons } \\
\text { Water recycled }=76 \% \\
\text { Wastewater }=20,499 \text { ktons }\end{array}$ & (Only effluents and wastewater) & $\begin{array}{l}\text { (Edison, 2017, } \\
\text { 2018) }\end{array}$ \\
\hline Orsted & $\begin{array}{l}\text { Water withdrawal }=1,380 \text { ktons } \\
\text { Wastewater discharge }=945 \text { ktons }\end{array}$ & $\begin{array}{c}\text { Hazardous waste }=193 \text { ktons } \\
\text { Non hazardous waste } 9 \text { ktons } \\
\text { Waste recycling }=77 \%\end{array}$ & $\begin{array}{l}\text { (Orsted, 2017, } \\
\text { 2018b, 2018a) }\end{array}$ \\
\hline MVV Energie & - & - & $\begin{array}{c}\text { (MVV Energie, } \\
\text { 2018) }\end{array}$ \\
\hline Fortum & $\begin{array}{c}\text { For production operations: } \\
\text { Water withdrawal = 2,140 Mtons } \\
\text { Water use = 2,003 Mtons } \\
\text { Water recycled = } 13 \text { Mtons }\end{array}$ & $\begin{array}{c}\text { Waste handling in energy } \\
\text { production plants }=34.7 \text { ktons } \\
\text { Material recovery }=9.35 \text { ktons } \\
\text { Energy recovery }=1.5 \text { ktons }\end{array}$ & (Fortum, 2018) \\
\hline Energa & $\begin{array}{c}\text { Water sourced }=38,189 \text { Mtons } \\
\text { (Given by source and by segment) } \\
\text { Wastewater }=20 \text { Mtons }\end{array}$ & $\begin{array}{c}\text { Total waste }=368.4 \text { ktons } \\
\text { Hazardous waste }=1.2 \text { ktons } \\
\text { Non hazardous }=45.7 \text { ktons } \\
\text { Waste recovered }=30.1 \text { ktons }\end{array}$ & (Energa, 2017) \\
\hline EDP & $\begin{array}{l}\text { Water use }=1,538 \text { Mtons } \\
\text { Wastewater }=1,520 \text { Mtons }\end{array}$ & $\begin{array}{c}\text { Waste }=349 \text { ktons } \\
\text { Hazardous waste }=5 \text { ktons } \\
\text { Recovered waste }=78 \%\end{array}$ & $\begin{array}{l}\text { (EDP, 2018a, } \\
2018 b)\end{array}$ \\
\hline Enea & $\begin{array}{c}\text { Water withdrawal given for each } \\
\text { Enea Group company } \\
\text { Total = 2,953 Mtons }\end{array}$ & $\begin{array}{l}\text { Waste for each company } \\
\text { Hazardous waste }=0.795 \text { ktons } \\
\text { Non hazardous }=1,492 \text { ktons }\end{array}$ & $\begin{array}{l}\text { (Enea, 2017a, } \\
\text { 2017b) }\end{array}$ \\
\hline SSE plc & $\begin{array}{c}\text { Water abstracted }=24,044 \text { Mtons } \\
\text { Water consumed }=7.6 \mathrm{Mtons} \\
\text { Water returned }=24,037 \text { Mtons }\end{array}$ & - & $\begin{array}{c}\text { (SSE PLC, } \\
2018 b, 2018 a)\end{array}$ \\
\hline
\end{tabular}




\begin{tabular}{|c|c|c|c|}
\hline Acciona & $\begin{array}{l}\text { Water consumption }=7,050 \text { ktons } \\
\text { By source: Recycled water } \\
\text { consumption }=3,660 \text { ktons }\end{array}$ & $\begin{array}{c}\text { Hazardous waste }=21 \text { ktons } \\
\begin{array}{c}\text { Non hazardous waste }=12,118 \text { ktons } \\
\text { Waste recovery }=43 \%\end{array}\end{array}$ & $\begin{array}{c}\text { (Acciona, } \\
2017 b, 2017 a)\end{array}$ \\
\hline Enel & $\begin{array}{l}\text { Water used by production process } \\
\qquad=96,300 \text { ktons } \\
\text { Treated wastewater used }=4.7 \%\end{array}$ & $\begin{array}{c}\text { Hazardous waste }=0.15 \text { ktons } \\
\text { Non hazardous waste }=8,846 \text { ktons } \\
\text { Waste recovery }=72 \%\end{array}$ & $\begin{array}{c}\text { (Enel, 2017, } \\
\text { 2018a, 2018b) }\end{array}$ \\
\hline
\end{tabular}

Regarding the circular economy, 13 categories of CE-related measures have been identified for the purpose of the analysis. Figure 2 provides a schematic presentation of a company producing energy and positions each identified category.

Figure 2: Schematic presentation of CE measures

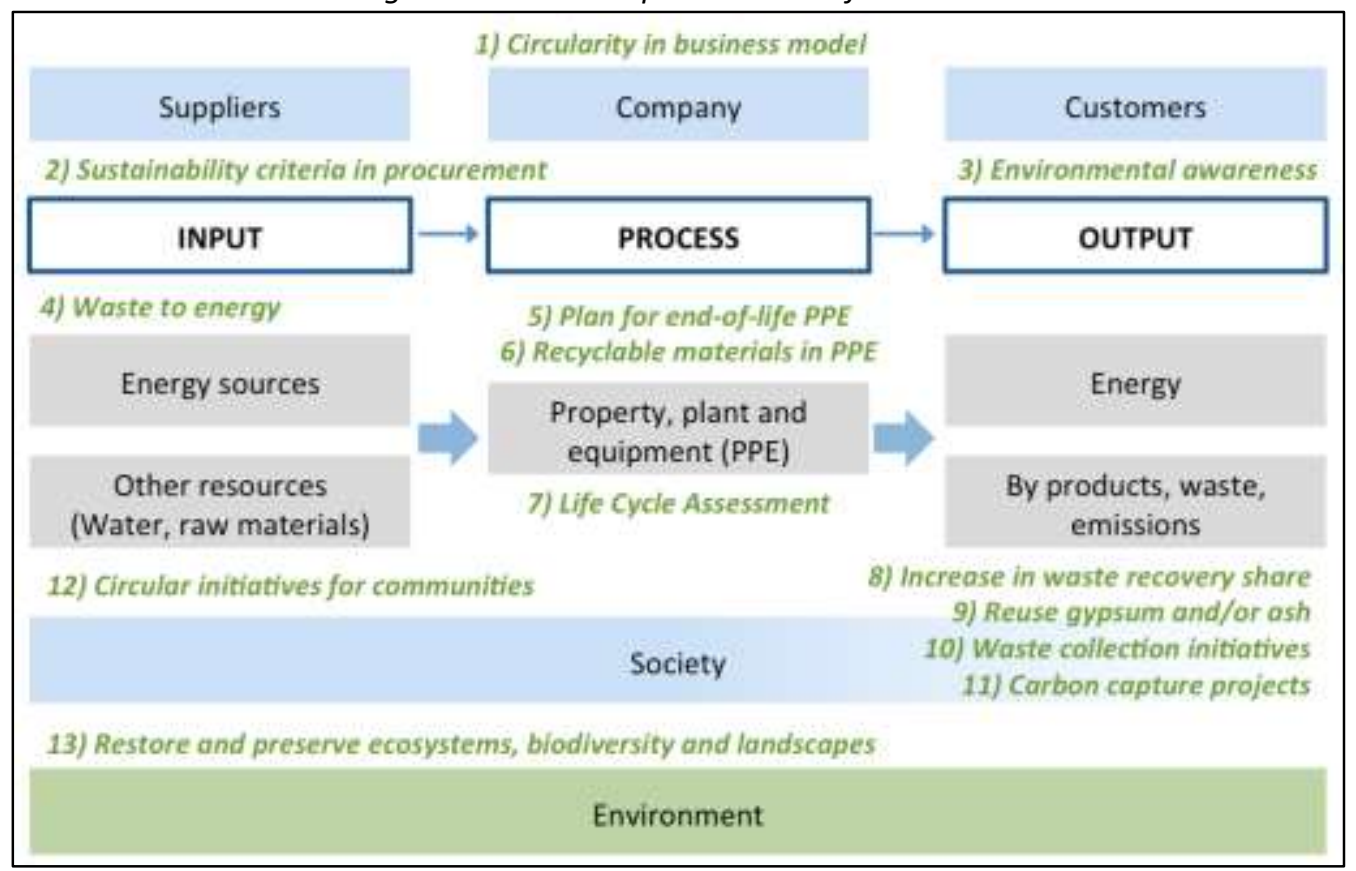

All companies engage in circularity-related measures, such as resource efficiency, emissions reduction and waste management. However, only 4 out of the 14 case companies mention their intention to integrate circularity in their business model in their report: Enel, Acciona, EDP and Fortum Corporation (CE measure 1). Those companies are among the largest with more than 8,000 employees and have operations internationally outside of Europe. In particular, Enel presents its vision on the CE based on 5 principles: waste minimisation and recovery, sustainable inputs, life cycle extension, product as a service and product sharing between users.

All companies require suppliers to comply with socio-environmental criteria through code of conduct and clauses in contracts (CE measure 2). Common procurement criteria concern human rights, working conditions, environment, corruption and safety. For instance, EDP Supplier Code of Conduct requires compliance with environmental legislation and standards, mitigation of environmental risks and impacts of activities, promotion of continuous streamlining of energy and natural resources, etc. 
Some companies engage in awareness initiatives dedicated to customers or local communities (CE measure 3 and 12). Enel is particularly active in engaging local communities and customers in the circular economy and spreading environmental awareness through conferences and publications on the $\mathrm{CE}$, recycling workshops, etc. MVV Energie is participating in educational programmes at school to improve attitudes towards water and resource management.

Waste as fuel (CE measure 4) is used by most case companies through different technologies and waste types. Four examples can be highlighted: Fortum with its cogeneration plant that combust refuse-derived fuels in Poland; Direct Energie with its units of methanation of organic and agricultural waste for biogas valorisation; Drax with its biomass from wood waste facility in the UK; and Orsted with its Renescience technology that transforms industrial waste into biogas and recyclable materials in the UK.

Regarding plants and equipments (CE measure 5 and 6), CE measures consider the life cycle of products and assets, establish plans for end-of-life stages and ensure the recoverability of component materials. For instance, EDP made a cooperation agreement with Thermal Recycling of Composites to implement a wind turbine blade recycling program. Enel's Future-e project turns decommissioned plants into eco-sustainable places. Another example is Fortum who applies CE principles in the demolition of its decommissioned coalfired plant. Such initiative requires a life cycle approach (CE measure 7). Five companies mention to perform LCA of environmental impacts of specific plants.

Measures focusing on waste, by-products and emissions include reduction of waste sent to landfill or incineration, reuse of combustion by-products, collection of waste within or outside the company and carbon capture development. Waste recovery percentages decreased for four companies (CE measure 8). Most companies operating thermal plants sell ash and gypsum for reuse as secondary raw materials e.g. in construction (CE measure 9). An example of waste collection initiatives is the campaign joined by Energa's employees for collecting used batteries and electronic equipment (CE measure 10). Concerning carbon capture (CE measure 11), Drax, Fortum and SSE participate in CCS pilot projects.

Finally, the restoration or conservation of the ecosystem (CE measure 13) can also be considered as a CE-related measure. All companies claim to engage in related initiatives. Examples include forest health (Drax), biodiversity conservation (Enel, Acciona, EDP, Edison) and bird nesting and migration (Energa).

Table 5 presents on a binary scale the CE measures undertaken for each case firm.

Table 5: CE measures by company ("1" if the measure is undertaken by the company, " 0 " if not)

\begin{tabular}{|c|c|c|c|c|c|c|c|c|c|c|c|c|c|c|}
\hline CE measure & 1) & 2) & 3) & 4) & 5) & 6) & 7) & 8) & 9) & 10) & 11) & 12) & 13) & Total \\
\hline Direct Energie & 0 & 1 & 0 & 1 & 0 & 0 & 0 & 0 & 0 & 1 & 0 & 0 & 1 & 4 \\
\hline Agder Energi & 0 & 1 & 0 & 1 & 0 & 0 & 1 & 0 & 0 & 0 & 0 & 0 & 1 & 4 \\
\hline Drax Group & 0 & 1 & 0 & 1 & 0 & 0 & 0 & 0 & 0 & 0 & 1 & 0 & 1 & 4 \\
\hline VERBUND & 0 & 1 & 0 & 0 & 1 & 0 & 0 & 0 & 1 & 0 & 0 & 0 & 1 & 4 \\
\hline Edison & 0 & 1 & 1 & 0 & 1 & 0 & 1 & 0 & 0 & 0 & 0 & 1 & 1 & 6 \\
\hline Orsted & 0 & 1 & 1 & 1 & 1 & 0 & 0 & 1 & 0 & 0 & 0 & 0 & 1 & 6 \\
\hline
\end{tabular}




\begin{tabular}{|c|c|c|c|c|c|c|c|c|c|c|c|c|c|c|}
\hline MVV Energie & 0 & 1 & 0 & 1 & 0 & 0 & 0 & 0 & 0 & 0 & 0 & 1 & 1 & 4 \\
\hline Fortum & 1 & 1 & 0 & 1 & 1 & 1 & 0 & 1 & 1 & 0 & 1 & 1 & 1 & 10 \\
\hline Energa & 0 & 1 & 0 & 0 & 0 & 0 & 0 & 0 & 1 & 1 & 0 & 1 & 1 & 5 \\
\hline EDP & 1 & 1 & 1 & 1 & 1 & 1 & 1 & 1 & 1 & 0 & 0 & 0 & 1 & 10 \\
\hline Enea & 0 & 1 & 0 & 0 & 0 & 0 & 0 & 0 & 0 & 1 & 0 & 0 & 1 & 3 \\
\hline SSE plc & 0 & 1 & 0 & 1 & 0 & 1 & 0 & 0 & 0 & 0 & 1 & 0 & 1 & 5 \\
\hline Acciona & 1 & 1 & 1 & 1 & 1 & 0 & 1 & 1 & 1 & 1 & 0 & 0 & 1 & 10 \\
\hline Enel & 1 & 1 & 1 & 1 & 1 & 0 & 1 & 0 & 1 & 1 & 0 & 1 & 1 & 10 \\
\hline
\end{tabular}

\section{Discussion}

When confronting findings from the literature with case studies, it has been observed that several CE techniques or measures described in the literature are implemented at corporate level. In all case companies, waste management goes beyond the disposal of waste. Waste recovery and recycling measures are undertaken at several levels of the supply chain. In particular, by-products from combustion such as ash and gypsum are supported by most case companies operating thermal plants. Regarding GHG emissions, CCS projects are being developed, although still at a preliminary development phase. Regarding product management, where energy is the product, all companies claim to implement energy efficiency measures through plant and grid modernisation works or customer-oriented services. In addition, most companies use energy recovery techniques, through combined heat and power or waste to energy plants.

This confrontation exercise highlights divergences between the literature and the case studies. Whether plans and provisions for end-of-life plants and equipment systematically integrate circular measures, is unclear. Reports indicate rather isolated initiatives, such as transforming selected decommissioned plants for new activities or pilot programs to recycle wind turbine blades. Products and services do not appear to be systematically assessed with a life cycle approach. Few companies report on performing LCA, most of them consisting of isolated studies. Moreover, the academic literature contains articles on the transformation of underused areas such as urban rooftops and closed landfills, into productive spaces (e.g. installation of wind turbines and solar panels). No case company has mentioned any related initiative in its report. Finally, whether the case companies are involved in industrial symbioses is unclear. However, this topic receives considerable academic attention, notably through studies of the Kalundborg case (Valentine, 2016; Taddeo et al., 2017) in which Orsted provides steam and power.

In order for energy companies to fully integrate CE in business models and provide the maximal contribution to the CE transition, the entire organisation and its stakeholders should be involved. This requires systemic innovation not just at technical level, but also at organisational and cultural level. As stated by Gorecki (2019), "implementation of innovations requires restructuring of all organisational management processes". He defined the concept of CE maturity with 5 dimensions: human resources, technical infrastructure, 
organisational culture, project management and organisation management (Gorecki, 2019). The degree of maturity would determine the readiness and potential for CE implementation in the company. In addition, CE must be implemented not only at organisational level, but also across supply chains, which requires cooperation with external stakeholders. The term circular supply chain management (CSCM) has been used by Geissdoerfer et al (2018) to define the "configuration and coordination of the supply chain to close, narrow, slow, intensify and dematerialise resource loops" (Geissdoerfer et al., 2018). CSCM is not limited to socio-environmental considerations in procurement decisions or public awareness initiatives, as implemented in most companies. It requires considering all available technologies and collaborations opportunities in order to optimise waste and resource management and minimise waste disposal and emissions.

Another requirement for a transition to the CE is to set targets, support decision-making and monitor progress. LCA are useful approaches to analyse the environmental impacts of business investments. Indicators commonly used in corporate reports include waste by type, waste recovery rate, water withdrawn by source, water consumed, and emissions. However, this does not provide indication on how decision-making is supported by circular criteria. For that purpose, a methodology has been proposed by Ellen Macarthur Foundation assess circularity at product- and company-level (Ellen Macarthur Foundation, 2015). This paper recommends using the Material Circularity Indicator $(\mathrm{MCl})$, along with complementary indicators of energy use, water use, toxicity and scarcity of CE measures.

This paves the way for a final remark on the scope of CE. The present research does not focus exclusively on material circulation and waste recovery. It expands the CE concept to the management and recovery of any by-product derived from industrial activities, including air emissions, and the management of their impacts. This reflects to the findings of McDowall et al (2017): while the European conception of the CE focuses on waste and resources, the Chinese perspective incorporates pollution, land use and other environmental pressures (McDowall et al., 2017). Achieving global consensus on the scope, definition and objectives of the CE would be useful in supporting the contribution of businesses.

\section{Conclusion}

This paper studies the engagement of companies in the CE. The approach consists of examining both the academic literature and cases of selected companies. The relevance of the focus on energy companies is justified by their key role in global value chains, their responsibility for environmental externalities, and their potential to bring significant contribution to the CE transition. Findings show that few case companies mention the CE or use terms associated with the CE concept in their report. However, they all report on waste, emissions and water management. In addition, they engage in circular techniques such as waste-to-energy, cogeneration, ash and gypsum recovery, CCS, and life cycle considerations of generation technologies. Commonalities are the environmental principles present in procurement policies, the engagement in environmental conservation, and the strategic 
focus on decarbonisation. However, it is unclear and unlikely that they adopt a systematic approach to integrate CE criteria in decision-making.

Several contributions can be highlighted. First, the literature analysis presents the evolution of knowledge on the CE strategies and energy businesses. Second, the case study analysis enables to highlight best practices, compare multiple European companies and identify opportunities and barriers to CE implementation at corporate level. Overall, it provides a better understanding of the current level of CE integration in business models of energy actors, and of the missing elements to maximise their role in the CE transition.

This paper opens the path for further research. First, areas that deserve in-depth examination include procurement policies, supply chain collaboration and end-of-life equipment planning. Second, a longitudinal perspective to evaluate efforts undertaken by businesses would enable to compare the speeds and assess the gap towards the CE. Third, further research could propose and apply a systematic approach with indicators and target setting methods. The alignment of corporate strategies to the CE requires methodological support to decision-making. Finally, global consensus and objectives are needed to ensure a coordinated transition to a circular and environmentally sustainable economy.

\section{References}

A. dos Reis Benatto, G., Espinosa, N. and Krebs, F. C. (2017) 'Life-Cycle Assessment of Solar Charger with Integrated Organic Photovoltaics', Advanced Engineering Materials, 19(8), pp. 1-7. doi: 10.1002/adem.201700124.

Acciona (2017a) 2017 Integrated Report.

Acciona (2017b) 2017 Sustainability Report.

Agder Energi (2017) Corporate Social Responsibility 2017.

Atasu, A. et al. (2018) 'Rethinking Sustainability in Light of the EU's New Circular Economy Policy', Harvard Business Review. Available at: https://hbr.org/2018/07/rethinkingsustainability-in-light-of-the-eus-new-circular-economy-policy.

Bianchini, A. et al. (2018) 'A new productive model of circular economy enhanced by digital transformation in the Fourth Industrial Revolution - An integrated framework and real case studies', in 23rd Summer School 'Francesco Turco' - Industrial Systems Engineering, pp. 221-227. Available at: https://www.scopus.com/inward/record. uri?eid=2-s2.085058188481\& partnerlD=40\&md5=47b3fbcac8f60e4013cad79f5417da6d.

Bučinskas, A., Kriipsalu, M. and Denafas, G. (2018) 'Proposal for feasibility assessment model for landfill mining and its implementation for energy generation scenarios', Sustainability (Switzerland), 10(8). doi: 10.3390/su10082882.

Buonocore, E. et al. (2019) 'Indicators of environmental performance to assess woodbased bioenergy production: A case study in Northern Italy', Journal of Cleaner Production. Elsevier Ltd, 221(2019), pp. 242-248. doi: 10.1016/j.jclepro.2019.02.272. 
Calabrese, A. et al. (2016) 'A fuzzy analytic hierarchy process method to support materiality assessment in sustainability reporting', Journal of Cleaner Production. Elsevier Ltd, 121, pp. 248-264. doi: 10.1016/j.jclepro.2015.12.005.

Caldera, H. T. S., Desha, C. and Dawes, L. (2019) 'Evaluating the enablers and barriers for successful implementation of sustainable business practice in "lean" SMEs', Journal of Cleaner Production. Elsevier Ltd, 218, pp. 575-590. doi: 10.1016/j.jclepro.2019.01.239.

Capece, G., Pillo, F. Di and Levialdi, N. (2013) 'The Performance Assessment of Energy Companies', in ICESD 2013: January 19-20, Dubai, UAE. Elsevier B.V., pp. 265-270. doi: 10.1016/j.apcbee.2013.05.046.

Christmann, P. (2018) 'Towards a More Equitable Use of Mineral Resources', Natural Resources Research. Springer US, 27(2), pp. 159-177. doi: 10.1007/s11053-017-9343-6.

Corcelli, F. et al. (2019) 'Transforming rooftops into productive urban spaces in the Mediterranean. An LCA comparison of agri-urban production and photovoltaic energy generation', Resources, Conservation and Recycling. Elsevier, 144(October 2018), pp. 321336. doi: 10.1016/j.resconrec.2019.01.040.

Cruz, N. C. et al. (2017) 'Ashes from fluidized bed combustion of residual forest biomass: recycling to soil as a viable management option', Environmental Science and Pollution Research. Environmental Science and Pollution Research, 24(17), pp. 14770-14781. doi: 10.1007/s11356-017-9013-6.

D'Amato, D., Korhonen, J. and Toppinen, A. (2019) 'Circular, Green, and Bio Economy: How Do Companies in Land-Use Intensive Sectors Align with Sustainability Concepts?', Ecological Economics. Elsevier, 158(April 2018), pp. 116-133. doi: 10.1016/j.ecolecon.2018.12.026.

Direct Energie (2017) Document de référence 2017.

Dong, S. et al. (2017) 'Assessment of comprehensive effects and optimization of a circular economy system of coal power and cement in Kongtong District, Pingliang City, Gansu Province, China', Sustainability (Switzerland), 9(5). doi: 10.3390/su9050787.

Donia, E., Mineo, A. M. and Sgroi, F. (2018) 'A methodological approach for assessing businness investments in renewable resources from a circular economy perspective', Land Use Policy. Elsevier, 76(January), pp. 823-827. doi: 10.1016/j.landusepol.2018.03.017.

Drax (2018) Annual report and accounts 2018.

Edison (2017) 2017 Financial Report. Available at: https://www.edison.it/sites/default/files/art_accordion_files/Edison_2017 Consolidated Financial Statements_per pubblicazione.pdf.

Edison (2018) 2018 Consolidated Non-Financial Disclosure. Available at: https://s3-uswest-2.amazonaws.com/ungc-

production/attachments/cop_2019/473159/original/Edison_5_DNF_ENG_per_sito.pdf?1554 210067. 
EDP (2018a) Annual Report 2018.

EDP (2018b) Sustainability Report 2018. doi: 10.1056/NEJM193612032152313.

Ellen Macarthur Foundation (2013) Towards the Circular Economy: Economic and business rationale for an accelerated transition.

Ellen Macarthur Foundation (2015) Circularity Indicators: An Approach to Measuring Circularity. Available at: https://doi.org/10.108/S1479-357120150000007007.

Enea (2017a) Consolidated financial statements of the Enea Capital Group for the financial year ended. Available at: https://investors.enea.pl/pr/387141/skonsolidowany-raportroczny-rs-2017.

Enea (2017b) Corporate Social Responsibility Report 2017. Available at: https://s3-uswest-2.amazonaws.com/ungc-

production/attachments/cop_2018/465519/original/Enea_Group_Corporate_Social_Respon sibilty_Report_2017.pdf?1531481217.

Enel (2017) Sustainability Report 2017.

Enel (2018a) Annual Report 2018. Available at: https://www.enel.com/content/dam/enelcom/governance_pdf/reports/annual-financial-report/2018/annual-report-2018.pdf.

Enel (2018b) Consolidated Non-financial Statement (NFS). Available at: https://www.enel.com/content/dam/enel-com/governance_pdf/reports/annual-financialreport/2018/dnf-2018-en.pdf.

Energa (2017) Corporate Social Responsibility Report 2017.

Fernández-Acero, F. J. et al. (2019) 'Valorisation of the microalgae Nannochloropsis gaditana biomass by proteomic approach in the context of circular economy', Journal of Proteomics. Elsevier, 193(October 2018), pp. 239-242. doi: 10.1016/j.jprot.2018.10.015.

Fortum (2018) Sustainability $2018 . \quad$ Available at: https://www.fortum.com/sites/g/files/rkxjap146/files/investordocuments/fortum_sustainability_2018.pdf.

Fuller, A. et al. (2018) Fly ash formation and characteristics from (co-)Combustion of an herbaceous biomass and a Greek lignite (Low-Rank Coal) in a pulverized fuel pilot-scale test facility, Energies. doi: 10.3390/en11061581.

Gallagher, J. et al. (2019) 'Adapting Stand-Alone Renewable Energy Technologies for the Circular Economy through Eco-Design and Recycling', Journal of Industrial Ecology, 23(1), pp. 133-140. doi: 10.1111/jiec.12703.

Gasbarro, F., Iraldo, F. and Daddi, T. (2017) 'The drivers of multinational enterprises' climate change strategies: A quantitative study on climate-related risks and opportunities', Journal of Cleaner Production. Elsevier Ltd, 160(December 2015), pp. 8-26. doi: 10.1016/j.jclepro.2017.03.018.

Geissdoerfer, M. et al. (2018) 'Business models and supply chains for the circular 
economy', Journal of Cleaner Production. Elsevier Ltd, 190, pp. 712-721. doi: 10.1016/j.jclepro.2018.04.159.

Gorecki, J. (2019) 'Circular Economy Maturity in Construction Companies', in IOP Conference Series: Materials Science and Engineering, p. 471. doi: 10.1088/1757899X/471/11/112090.

Islam, K. M. N. and Jashimuddin, M. (2017) 'Reliability and economic analysis of moving towards wastes to energy recovery based waste less sustainable society in Bangladesh: The case of commercial capital city Chittagong', Sustainable Cities and Society. Elsevier B.V., 29, pp. 118-129. doi: 10.1016/j.scs.2016.11.011.

de Jesus, A. and Mendonça, S. (2018) 'Lost in Transition? Drivers and Barriers in the Ecoinnovation Road to the Circular Economy', Ecological Economics. Elsevier, 145(August 2017), pp. 75-89. doi: 10.1016/j.ecolecon.2017.08.001.

Jørgensen, M. S. and Remmen, A. (2018) 'A Methodological Approach to Development of Circular Economy Options in Businesses', in 25th CIRP Life Cycle Engineering (LCE) Conference. The Author(s), pp. 816-821. doi: 10.1016/j.procir.2017.12.002.

Kalmykova, Y., Sadagopan, M. and Rosado, L. (2018) 'Circular economy - From review of theories and practices to development of implementation tools', Resources, Conservation and Recycling. Elsevier, 135(February 2017), pp. 190-201. doi: 10.1016/j.resconrec.2017.10.034.

Kirchherr, J. et al. (2018) 'Barriers to the Circular Economy: Evidence From the European Union (EU)', Ecological Economics. Elsevier, 150(April), pp. 264-272. doi: 10.1016/j.ecolecon.2018.04.028.

Korhonen, J., Honkasalo, A. and Seppälä, J. (2018) 'Circular Economy: The Concept and its Limitations', Ecological Economics. Elsevier B.V., 143, pp. 37-46. doi: 10.1016/j.ecolecon.2017.06.041.

Laumann, F. and Tambo, T. (2018) 'Enterprise architecture for a facilitated transformation from a linear to a circular economy', Sustainability (Switzerland), 10(11). doi: $10.3390 /$ su10113882.

Lieder, M. et al. (2017) 'Towards circular economy implementation in manufacturing systems using a multi-method simulation approach to link design and business strategy', International Journal of Advanced Manufacturing Technology, 93(5-8), pp. 1953-1970. doi: 10.1007/s00170-017-0610-9.

Manara, P. and Zabaniotou, A. (2016) 'Co-valorization of Crude Glycerol Waste Streams with Conventional and/or Renewable Fuels for Power Generation and Industrial Symbiosis Perspectives', Waste and Biomass Valorization. Springer Netherlands, 7(1), pp. 135-150. doi: 10.1007/s12649-015-9439-3.

Masi, D. et al. (2018) 'Towards a more circular economy: exploring the awareness, practices, and barriers from a focal firm perspective', Production Planning and Control. 
Taylor \& Francis, 29(6), pp. 539-550. doi: 10.1080/09537287.2018.1449246.

McDowall, W. et al. (2017) 'Circular Economy Policies in China and Europe', Journal of Industrial Ecology, 21(3), pp. 651-661. doi: 10.1111/jiec.12597.

Millward-Hopkins, J. and Purnell, P. (2019) 'Circulating blame in the circular economy: The case of wood-waste biofuels and coal ash', Energy Policy. Elsevier Ltd, 129(February), pp. 168-172. doi: 10.1016/j.enpol.2019.02.019.

MVV Energie (2018) Annual Report. Available at: https://www.mvv.de/media/en/media/downloads/investor_relations/geschaeftsjahr_2018/ berichte_22/GB_2018_dt.pdf.

Naims, H. (2016) 'Economics of carbon dioxide capture and utilization-a supply and demand perspective', Environmental Science and Pollution Research. Environmental Science and Pollution Research, 23(22), pp. 22226-22241. doi: 10.1007/s11356-016-6810-2.

$\mathrm{Ng}$, K. S. and Martinez Hernandez, E. (2016) 'A systematic framework for energetic, environmental and economic (3E) assessment and design of polygeneration systems', Chemical Engineering Research and Design. Institution of Chemical Engineers, 106(0), pp. 125. doi: 10.1016/j.cherd.2015.11.017.

Oghazi, P. and Mostaghel, R. (2018) 'Circular business model challenges and lessons learned-An industrial perspective', Sustainability (Switzerland), 10(3), pp. 1-19. doi: $10.3390 /$ su10030739.

Orsted (2017) Sustainability Report 2017.

Orsted (2018a) Annual report 2018.

Orsted (2018b) ESG performance report 2018.

Palm, E., Nilsson, L. J. and Åhman, M. (2016) 'Electricity-based plastics and their potential demand for electricity and carbon dioxide', Journal of Cleaner Production. Elsevier Ltd, 129, pp. 548-555. doi: 10.1016/j.jclepro.2016.03.158.

Portillo-Tarragona, P. et al. (2018) 'Classification and measurement of the firms' resources and capabilities applied to eco-innovation projects from a resource-based view perspective', Sustainability (Switzerland), 10(9). doi: 10.3390/su10093161.

van der Roest, E. et al. (2017) 'Converting Waste Toilet Paper into Electricity: A First-Stage Technoeconomic Feasibility Study', Energy Technology, 5(12), pp. 2189-2197. doi: 10.1002/ente.201700247.

de Selliers, D. and Spataru, C. (2018) 'Energy-Materials Nexus for a Low Carbon Energy System', in The Energy Transition: Current and Future challenges to energy security - 3rd AIEE Energy Symposium. Milan, pp. 92-94.

Sousa-Zomer, T. T. et al. (2017) 'Lifecycle management of product-service systems: a preliminary investigation of a white goods manufacturer', in The 9th CIRP IPSS Conference: Circular Perspectives on Product/Service-Systems. The Author(s), pp. 31-36. doi: 


\subsection{6/j.procir.2017.03.041.}

Sousa-Zomer, T. T. et al. (2018) 'Exploring the challenges for circular business implementation in manufacturing companies: An empirical investigation of a pay-per-use service provider', Resources, Conservation and Recycling. Elsevier, 135(January 2017), pp. 313. doi: 10.1016/j.resconrec.2017.10.033.

SSE PLC (2018a) Annual Report 2018.

SSE PLC (2018b) Sustainability Report 2018.

Stropnik, R. et al. (2018) 'Reducing environmental impacts of the ups system based on PEM fuel cell with circular economy', Energy, 165, pp. 824-835. doi: 10.1016/j.energy.2018.09.201.

Taddeo, R. et al. (2017) 'Industrial symbiosis, networking and innovation: The potential role of innovation poles', Sustainability (Switzerland), 9(2), pp. 1-17. doi: $10.3390 /$ su9020169.

United Nations (1987) Report of the World Commission on Environment and Development: Our Common Future.

United Nations Global Compact (2016) 'The UN Global Compact Ten Principles and the Sustainable Development Goals: Connecting, Crucially', White Paper.

Valentine, S. V. (2016) 'Kalundborg Symbiosis: Fostering progressive innovation in environmental networks', Journal of Cleaner Production. Elsevier Ltd, 118, pp. 65-77. doi: 10.1016/j.jclepro.2016.01.061.

Velenturf, A. P. M. (2017) 'Initiating resource partnerships for industrial symbiosis', Regional Studies, Regional Science. Routledge, 4(1), pp. 117-124. doi: 10.1080/21681376.2017.1328285.

Veleva, V., Bodkin, G. and Todorova, S. (2017) 'The need for better measurement and employee engagement to advance a circular economy: Lessons from Biogen's "zero waste" journey', Journal of Cleaner Production. Elsevier Ltd, 154, pp. 517-529. doi: 10.1016/j.jclepro.2017.03.177.

Verbund (2018) Integrated Annual Report 2018.

Vogtlander, J. G. et al. (2017) 'Combined analyses of costs, market value and eco-costs in circular business models: eco-efficient value creation in remanufacturing', Journal of Remanufacturing. Journal of Remanufacturing, 7(1), pp. 1-17. doi: 10.1007/s13243-0170031-9.

Walls, J. L. and Paquin, R. L. (2015) 'Organizational Perspectives of Industrial Symbiosis', Organization \& Environment, 28(1), pp. 32-53. doi: 10.1177/1086026615575333.

Wen, Z. and Meng, X. (2015) 'Quantitative assessment of industrial symbiosis for the promotion of circular economy: A case study of the printed circuit boards industry in China's Suzhou New District', Journal of Cleaner Production. Elsevier Ltd, 90, pp. 211-219. doi: 
10.1016/j.jclepro.2014.03.041.

World Bank (2017) 'The Growing Role of Minerals and Metals for a Low Carbon Future', World Bank Publications, (June). Available at: http://documents.worldbank.org/curated/en/207371500386458722/pdf/117581-WPP159838-PUBLIC-ClimateSmartMiningJuly.pdf.

WRI and WBCSD (2010) The Greenhouse Gas Protocol: A Corporate Accounting and Reporting Standard.

Yin, R. K. (2003) Case Study Research: Design and Research. SAGE Publi. Beverly Hills.

Zamfir, A. M., Mocanu, C. and Grigorescu, A. (2017) 'Circular economy and decision models among European SMEs', Sustainability (Switzerland), 9(9). doi: 10.3390/su9091507. 